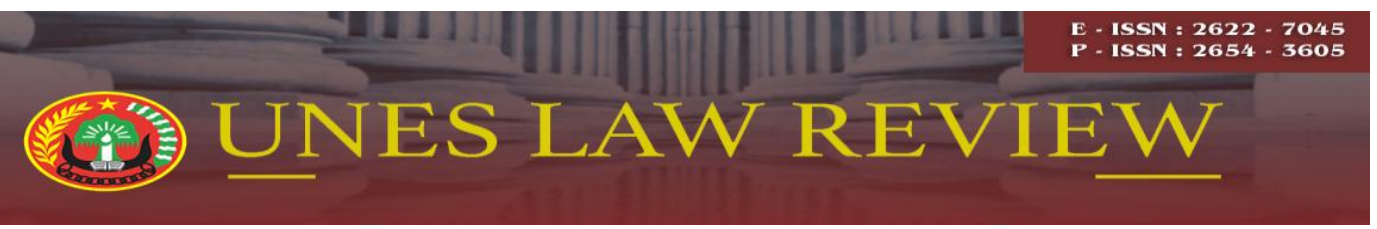

Email : uneslawreview@gmail.com Online : http://review-unes.com/index.php/law/index

Volume 1, Issue 4, Juni 2019

E-ISSN : 2622-7045

P-ISSN : 2654-3605

\title{
LEGALITAS PENGGUNAAN GPS SELAMA BERKENDARA MELALUI SMARTPHONE PASCA PUTUSAN MK NO. 23/PUU-XVI/2018
}

\author{
Xavier Nugraha $^{1}$, Anneta Cornelia Budianto ${ }^{2}$, Rizky Hadiwidjayanti ${ }^{3}$ \\ ${ }^{1}$ Masyarakat Yuris Muda Airlangga, Universitas Airlangga \\ Email : xavier.nugraha-2015@fh.unair.ac.id \\ ${ }^{2}$ Masyarakat Yuris Muda Airlangga, Universitas Airlangga \\ Email : anneta cornelia@yahoo.com \\ ${ }^{3}$ Masyarakat Yuris Muda Airlangga, Universitas Airlangga \\ Email : Rizkyhadiwidjayanti@gmail.com
}

\begin{abstract}
Nowadays, using GPS as a navigator from smartphone is increasing, but it turns out there is a legal issue. This is related to the concept of driving with full concentration in Article 106 paragraph (1) of Law Number 22 Year 2009. In the explanation of Article 106 paragraph (1), there is an ambiguity in the interpretation between being able to use GPS, as long as it does not cause a concentration disturbance in driving or it is prohibited from using a cellphone at all, which means, using GPS via a smartphone is not allowed. This research is a study using normative law, with primary legal materials is legislation related to the use of GPS through smartphones during driving, such as, Law Number 22 Year 2009 concerning Road Traffic and Transportation and Constitutional Court Decision No. 23 / PUU-XVI / 2018, while materials Secondary law consists of books, journals, and other sources that are relevant. Based on the results of this study, it was found that the Constitutional Court provided an interpretation, that using GPS via a smartphone during driving was permitted, but it should not cause a concentration disturbance while driving and the application of such sanctions was casuistic.
\end{abstract}

Keywords: GPS, smartphone, driving with full concentration

\section{PENDAHULUAN}

Saat ini, manusia telah berada berada dalam sebuah era yang sarat dengan kemajuan teknologi. Kemajuan teknologi tersebut adalah suatu hal yang tidak bisa dihindari dalam kehidupan ini, karena kemajuan teknologi akan berjalan sesuai dengan kemajuan ilmu pengetahuan. ${ }^{1}$ Setiap

\footnotetext{
${ }^{1}$ Muhamad Ngafifi, Kemajuan Teknologi Dan
} Pola Hidup Manusia Dalam Perspektif Sosial Budaya, inovasi teknologi yang diciptakan oleh manusia tersebut, bertujuan untuk memudahkan manusia dalam beraktivitas. Hal tersebut terbukti dengan banyaknya inovasi-inovasi teknologi yang telah dihasilkan dalam dekade terakhir ini yang secara faktual memudahkan hidup manusia. ${ }^{2}$

Jurnal Pembangunan Pendidikan: Fondasi dan Aplikasi, Volume 2, Nomor 1 Juni 2012. Hlm. 34.

2 Ahmar Amad, Perkembangan Teknologi Komunikasi Dan Informasi: Akar Revolusi Dan 
Salah satu inovasi yang lahir dalam rangka memudahkan hidup manusia tersebut adalah Global Positioning System (selanjutnya disebut GPS).

GPS merupakan sebuah sistem untuk menentukan posisi dan navigasi secara global dengan menggunakan satelit dan metode Triangulasi. ${ }^{3}$ Ada 4 (empat) fungsi pokok dari GPS, antara lain : ${ }^{4}$

1. Lokasi

Digunakan untuk menentukan dimana lokasi suatu titik dipermukaan bumi berada,

2. Navigasi

Membantu mencari lokasi suatu titik di bumi

3. Tracking

Membantu untuk memonitoring pergerakan obyek dan membantu memetakan posisi tertentu, dan perhitungan jaringan terdekat

4. Timing

Dapat dijadikan dasar penentuan jam seluruh dunia, karena memakai jam atom yang jauh lebih presesi di banding dengan jam bisa.

GPS juga dapat menentukan variabelvariabel turunan terkait lokasi, seperti: (1) kecepatan, (2) percepatan (Akselerasi), (3) arah laju, (4) jarak, dan (5) selang waktu. ${ }^{5}$

Berbagai Standarnya, Jurnal Dakwah Tabligh, Volume 13, Nomor 1 Juni 2012.Hlm. 138.

3 Yosephat Suryo Susilo et.al., Sistem Pelacakan Dan Pengamanan Kendaraan Berbasis Gps Dengan Menggunakan Komunikasi Gprs, Jurnal Ilmiah Widya Teknik, Volume 13, Nomor 1 Mei 2014.Hlm.22.

4 Putu Agus Yudisuda Indrakarna et.al., Rancang Bangun Sistem Informasi Pelacakan Dan Pemantauan Paket Kiriman Berbasis Web Dengan Bantuan Mobile Android, Volume 1,Nomor 2 2012.Hlm.7.

5 Oktri Mohammad Firdaus, Analisis Implementasi Global Positioning System (Gps) Pada Moda Transportasi Di Pt. "X", Proceeding Seminar on
Dengan fungsi-fungsi yang dimiliki oleh GPS tersebut, tentu sangat membantu kehidupan manusia, khususnya terkait informasi koordinat suatu benda/orang. Bahkan, dalam perkembangannya GPS tersebut digunakan dalam hampir di setiap sendi-sendi kehidupan. Misal digunakan untuk mendukung sistem pertahanan militer dengan jalan memantau pergerakan musuh saat terjadi peperangan, menjadi penuntun arah jatuhnya bom,dsb. ${ }^{6}$ GPS juga berfungsi untuk memantau pergerakan tanah di bumi. Dengan hal itu maka para pakar Geologi dapat memperkirakan kemungkinan terjadinya gempa di suatu wilayah. ${ }^{7}$

Salah satu fungsi GPS yang sering digunakan oleh khalayak umum adalah sebagai alat navigasi. GPS digunakan untuk mempermudah untuk menemukan titik koordinat suatu lokasi, khususnya ketika berpergian menuju lokasi yang tidak diketahui. GPS sering sekali diandalkan untuk memandu menuju lokasi yang dituju. Dalam rangka menggunakan GPS sebagai navigator, umumnya ada 2 (dua) tipe GPS yang digunakan, yaitu GPS yang menjadi kesatuan tak terpisahkan dalam perangkat

Application and Research in Industrial Technology (SMART), Yogyakarta,2010.Hlm.84.

6 (Nadia, "Fungsi GPS"), http://www. Fungsi klopedia.com/fungsi-gps/, diunduh pada Jumat, 8 Maret 2019, jam 22.00WIB

${ }^{7}$ Ibid. 
mobil/kendaraan (integrated) dan GPS melalui smartphone. ${ }^{8}$

Tipe GPS yang pertama, yaitu GPS yang terpasang menjadi satu dengan kendaraan, umumnya hanya terpasang pada mobil saja, seperti mobil-mobil keluaran tipe terbaru dari Hyundai, sepeti New Santa Fe, New Tucson, New i-20, New Grand Avega sudah dilengkapi dengan alat GPS di mobilnya. ${ }^{9} \quad$ Tipe yang kedua, yaitu GPS melalui smartphone. Tipe ini umumnya paling banyak digunakan oleh masyarakat, karena hampir seluruh masyrakat kini memiliki smartphone, bahkan pada tahun 2019, diprediksi ada sekitar 92 juta pengguna smartphone di Indonesia. ${ }^{10}$

Dewasa ini, penggunan sistem GPS untuk navigasi melalui smartphone juga digunakan untuk mencari nafkah oleh pengemudi ojek/taksi online. ${ }^{11}$ Pengemudi transportasi online (mitra) menggunakan GPS untuk menentukan titik pemesanan

${ }^{8}$ ( Arris Riehady, "Nasib GPS di Mobil Setelah Ada Larangan Menggunakannya"), https://www.seva.id /otomotif/blog/nasib-gps-di-mobil-setelah-ada-

larangan-menggunakannya//, diunduh pada Jumat, 8 Maret 2019, jam 22.43 WIB)

${ }^{9}$ (Edi Nugroho, "Simak, Keuntungan Membeli Mobil yang Dilengkapi GPS"), http://banjarmasin .tribunnews.com/2017/02/14/simakkeuntunganmembeli -mobil-yang-dilengkapi-gps, diunduh pada Jumat, 8 Maret 2019, jam 23.01 WIB)

10 (Emanuel Kure dan Abdul Muslim, "Pengguna Smartphone RI Tumbuh 30\%"), https://id.beritasatu.com/home/pengguna-smartphoneri-tumbuh-30/143720, diunduh pada Jumat, 8 Maret 2019, jam 23.10 WIB)

${ }^{11}$ (Irman Rismawan, "GOJEK Beri Cara Aman Driver Ojek Online Gunakan GPS"), http://www.tribunnews.com/techno/2019/02/12/gojekberi-cara-aman-driver-ojek-online-gunakan-gps, diunduh pada Jumat, 8 Maret 2019, jam 23.50WIB) pengguna jasa dan dan menentukan posisi pengemudi transportasi online agar bisa sampai ke lokasi dimana pengguna jasa tersebut berada. ${ }^{12}$ Sehingga bisa dikatakan bahwa penggunaan GPS untuk navigasi melalui smartphone tersebut merupakan hal yang esensial dalam pekerjaan pengemudi ojek/taksi online. Bahkan bisa dibilang bahwa pekerjaan tersebut akan sangat sulit dilakukan jika tidak memiliki GPS melalui smartphone, karena selain sulitnya menentukan titik koordinasi penjemputan dan pengantaran, model aplikasi transportasi online juga hanya dapat dipasang dan dioperasikan melalui Smartphone.

Meskipun penggunan GPS untuk navigasi melalui smartphone ini banyak digunakan oleh masyarakat, bahkan menjadi unsur esensial bagi beberapa orang untuk mencari nafkah, namun terkait legalitas akan penggunan GPS melalui smartphone ini ternyata belum memiliki kejelasan. Hal ini disebabkan dalam Pasal 106 ayat (1) Undang-Undang Nomor 22 Tahun 2009 Tentang Lalu Lintas dan Angkutan Jalan (selanjutnya disebut UU LLAJ), dikatakan bahwa, setiap orang yang mengemudikan kendaraan bermotor di jalan wajib mengemudikan kendaraannya dengan wajar dan penuh konsentrasi. Dalam penjelasan

12 (Eko Aria Wibowo, "GPS Ponsel Akan Dirazia, Ini Trik Pengemudi Ojek Online"), https://otomotif.tempo.co/read/1172340/gps-ponselakan-dirazia-ini-trik-pengemudi-ojek-online/full\&view =ok, diunduh pada Sabtut, 9 Maret 2019, jam 00.07 WIB) 
Pasal 106 ayat (1) UU LLAJ tersebut, dikatakan bahwa:

Yang dimaksud dengan "penuh konsentrasi" adalah setiap orang yang mengemudikan Kendaraan Bermotor dengan penuh perhatian dan tidak terganggu perhatiannya karena sakit, lelah, mengantuk, menggunakan telepon atau menonton televisi atau video yang terpasang di Kendaraan, atau meminum minuman yang mengandung alkohol atau obat-obatan sehingga memengaruhi kemampuan dalam mengemudikan Kendaraan.

Dalam penjelasan pasal tersebut, secara gramatikal seolah penggunan GPS melalui smartphone diperbolehkan, asal tidak menggangu konsentrasi. Namun pasal tersebut dapat pula ditafsirkan, bahwa penggunan telepon genggam seperti apapun tidak diperbolehkan. Tafsiran inilah yang acapkali digunakan oleh penegak hukum. ${ }^{13}$ Ambiguitas ini mengakibatkan, orang yang menggunakan GPS untuk navigasi melalui smartphone, dapat terancam melanggar Pasal 106 ayat (1) UU LLAJ dan terancam sanksi pidana, sebagaimana diatur dalam ketentuan Pasal 283 UU LLAJ, yaitu dipidana dengan pidana kurungan paling lama 3 (tiga) bulan atau denda paling banyak Rp750.000,00 (tujuh ratus lima puluh ribu rupiah).

${ }^{13}$ (Mohammad Zacky, "Pakai GPS Sambil Nyetir Ditilang, Driver Online: Jangan Hanya Kami”), https://news.detik.com/berita/d-3898409/pakai-gpssambil-nyetir-ditilang-driver-online-jangan-hanyakami, Sabtu, 9 Maret 2019, jam 06.00 WIB)
Banyak kalangan di masyarakat merasa, bahwa UU LLAJ tersebut adalah produk legislasi yang ketinggalan zaman, karena menggangap ketika UU tersebut dibuat, tidak ada orang yang menggunakan GPS untuk navigasi melalui smartphone, bahkan pada saat itu, pekerjaan sebagai ojek/taksi online belumlah menjamur seperti sekarang.

Dalam rangka memberikan kepastian hukum terkait indikator "menggunakan telepon genggam seperti apa yang dapat menggangu konsentrasi" sesuai jaminan pasal Pasal 28D ayat (1) Undang-Undang Dasar Negara Republik Indonesia 1945(selanjutnya disebut UUD NRI 1945) ${ }^{14}$ dan dalam rangka menjamin hak untuk bekerja sesuai pasal 28D ayat (2) UUD NRI 1945, maka, masyrakat mengajukan gugatan terkait Pasal 106 ayat (1) dan Pasal 283 UU LLAJ ke Makahamah Konstitusi , mengingat Makhamah Konstitusi adalah pengawal hakhak konsitusional warga negara (the guardian of citizen's constitutional rights). ${ }^{15}$

Dalam putusannya, Makhamah Konstitusi secara bulat menolak pengujian Pasal 106 ayat (1) dan Pasal 283 UU LLAJ, yang berarti kedua pasal yang mewajibkan pengendara penuh konsentrasi/perhatian itu

\footnotetext{
${ }^{14}$ Penggunan Frasa UUD NRI 1945 dipilih karena UUD NRI 1945 adalah UUD hasil amandemen

15 Janedri M.Gaffar, Peran Makhamah Konstitusi dalam Perlindungan Hak Asasi Manusia, Jurnal Konstitusi, Volume 10, Nomor 1 Maret 2013.Hal.13.
} 
dinyatakan tetap konstitusional dan tetap berlaku. $^{16}$

Dalam pertimbangannya Makhamah Konstitusi menilai, bahwa menggunakan GPS yang terdapat dalam smartphone dapat menggangu konsentrasi ${ }^{17}$, sehingga permohonan pemohon untuk mengecualikan larangan dalam Pasal 106 ayat (1) dan Pasal 283 UU LLAJ untuk penggunaan aplikasi sistem navigasi yang berbasiskan satelit yang biasa disebut GPS yang terdapat dalam smartphone tidak dapat dikabulkan.

Dengan dikeluarkannya putusan Makahamah Konstitusi tersebut, semakin menambah polemik di masyrakat terkait legalitas penggunan GPS tersebut. Apakah penggunan GPS melalui smartphone pasti dikatakan menggangu konsentrasi? Apakah penggunan GPS melalui smartphone sama sekali tidak diperbolehkan? Apakah ada kondisi-kondisi tertentu dimana masyrakat dapat menggunakan GPS melalui smartphone? Berdasarkan latar belakang di atas, penulis tertarik untuk menganalisa terkait" Legalitas Penggunaan Global Positioning System (GPS) Pasca Putusan Makhamah Konstitusi No 23/PUUXVI/2018”.

\footnotetext{
16 (Agus Sahbani, “Alasan MK Tetap Larang Penggunaan GPS"), https://www.hukumonline.com /berita/baca/lt5c542c0cb2fdf/alasan-mk-tetap-larangpenggunaan-gps, diunduh pada Sabtu,9 Maet 2019, jam $08.00 \mathrm{WIB}$ )

${ }^{17}$ Ibid.
}

\section{METODE PENELITIAN}

Sifat penelitian yang digunakan adalah penelitian yuridis normatif. Pendekatan yang digunakan dalam penelitian hukum normatif ini adalah pendekatan peraturan perundangu-ndangan (statute approach) pendekatan konseptual (conceptual approach), dan pendekatan kasus (case approach).

Penelitian ini dilakukan melalui penelitian kepustakaan dengan cara meneliti bahan pustaka atau data sekunder, yang dalam hal ini berupa peraturan perundang-undangan dan data lain yang dapat digunakan untuk mendidentifikasi dan mengevaluasi legalitas penggunan GPS di Indonesia. $^{18}$

\section{HASIL PENELITIAN DAN ANALISIS}

Ambiguitas Larangan Penggunan GPS melalui Smartphone dalam UndangUndang Nomor 22 Tahun 2009

Dalam Pasal 3 UU LLAJ, dikatakan bahwa lalu lintas dan angkutan jalan dilaksanakan dengan tujuan:

1. terwujudnya pelayanan Lalu Lintas dan Angkutan Jalan yang aman, selamat, tertib, lancar, dan terpadu dengan moda angkutan lain untuk mendorong perekonomian nasional, memajukan kesejahteraan umum, memperkukuh persatuan dan kesatuan bangsa, serta mampu menjunjung tinggi martabat bangsa;

2. terwujudnya etika berlalu lintas dan budaya bangsa; dan

${ }^{18}$ Mukti Fajar dan Yulianto Achmad, Dualisme Penelitian Hukum Normatif dan Empiris, Pustaka Pelajar, Yogyakarta,2013. Hlm.185 
3. terwujudnya penegakan hukum dan kepastian hukum bagi masyarakat.

Dari pasal tersebut, dapat dilihat bahwa, UU LLAJ ini bertujuan untuk membina dan menyelenggarakan lalu lintas dan angkutan jalan yang aman, tertib, berfokus pada keselamatan, dan kelancaran untuk kepentingan semua lapisan masyarakat. Hal tersebut menunjukkan, bahwa segala ketentuan yang ada dalam UU LLAJ pada pokoknya akan bermuara bagaimana terselenggaranya keamanan, ketertiban, keselamatan, dan kelancaran dalam berlalu lintas itu sendiri. ${ }^{19}$

Dalam rangka menciptakan kondisi lalu lintas yang aman tersebut, salah satu aturan yang diatur adalah terkait pasal 106 ayat (1) UU LLAJ, yang menjelaskan bahwa Setiap orang yang mengemudikan Kendaraan Bermotor di Jalan wajib mengemudikan kendaraannya dengan wajar dan penuh konsentrasi. Berdasarkan ketentuan tersebut, terdapat 2 (dua) hal yang wajib dilakukan oleh seorang pengemudi yaitu: pertama, seorang pengemudi wajib mengemudikan kendaraannya dengan wajar. Mengenai konsep "mengemudikan kendaraan dengan wajar" tersebut,secara ekplisiti kita tidak akan menemukan aturannya. Namun, mengacu pendapat Marcus Priyo Gunarto ${ }^{20}$, bahwa untuk menemukan makna "mengemudikan secara wajar" tersebut dapat

\footnotetext{
${ }^{19}$ Putusan MK No 23/PUU-XVI/2018 Hal.125.

${ }^{20}$ Putusan MK No 23/PUU-XVI/2018 Hal.93.
}

dilakukan dengan mengkaji UU LLAJ secara komperhensif, dimana terkait konsep "mengemudikan secara wajar" ini harus dikaitkan dengan pasal 106 ayat (4 ) UU LLAJ. $^{21}$ Hal serupapun disampaikan oleh Nurhasan Ismail $^{22}$, bahwa indikator mengendari dengan wajar atau tidak adalah bila seseorang mengendarai sesuai dengan ketentuan dalam pasal 106 ayat (4) UU LLAJ.

Kedua, adalah "penuh konsentrasi". Mengacu pasal 176 Lampiran II UndangUndang Nomor 12 Tahun 2011 Tentang Pembentukan Peraturan PerundangUndangan, dikatakan bahwa, penjelasan berfungsi sebagai tafsir resmi pembentuk Peraturan Perundang-undangan atas norma tertentu dalam batang tubuh. Dalam penjelasan pasal 106 ayat (1) UU LLAJ tersebut, dikatakan bahwa:

Yang dimaksud dengan "penuh konsentrasi" adalah setiap orang yang mengemudikan Kendaraan Bermotor dengan penuh perhatian dan tidak terganggu perhatiannya karena sakit, lelah, mengantuk, menggunakan telepon atau menonton televisi atau video yang terpasang di Kendaraan, atau meminum minuman yang mengandung

${ }^{21}$ Setiap orang yang mengemudikan Kendaraan Bermotor di Jalan wajib mematuhi ketentuan:a. rambu perintah atau rambu larangan; b. Marka Jalan; c. Alat Pemberi Isyarat Lalu Lintas; d. gerakan Lalu Lintas; e. berhenti dan Parkir; f. peringatan dengan bunyi dan sinar; g. kecepatan maksimal atau minimal; dan/atau h. tata cara penggandengan dan penempelan dengan Kendaraan lain vide pasal 106 ayat (4) UU LLAJ

${ }^{22}$ Putusan MK No 23/PUU-XVI/2018 Hal.104. 
alkohol atau obat-obatan sehingga memengaruhi kemampuan dalam mengemudikan Kendaraan.

Jika dilihat dari unsur-unsur konsep "penuh konsentrasi" dalam penjelasan Pasal 106 ayat (1) tersebut seolah menimbulkan ambiguitas. Jika digunakan penafsiran gramatikal (menafsirkan kata-kata dalam undang-undang sesuai kaidah bahasa dan kaidah hukum tatabahasa) ${ }^{23}$, maka dapat dilihat bahwa unsur penuh konsentrasi adalah:

1. penuh perhatian;

2. tidak terganggu perhatiannya karena:

a. sakit,

b. lelah,

c. mengantuk,

d. menggunakan telepon,

e. menonton televisi atau video yang terpasang di Kendaraan, atau

f. meminum minuman yang mengandung alkohol atau obat-obatan;

3. memengaruhi kemampuan dalam mengemudikan Kendaraan.

Jika dilihat dari unsur dalam penjelasan pasal 106 ayat (1) tersebut, dapat dilihat bahwa 3 (tiga) unsur tersebut adalah kumulatif. Jika penafsiran gramatikal ini dikaitkan dengan penggunan GPS melalui smartphone, maka seseorang masih dapat menggunakan GPS melalui smartphone, asalkan orang tersebut tidak terganggu perhatiannya.

23 Agus Priono et.al., Penerapan Teori Penafsiran Hukum Oleh Hakim Sebagai Upaya Perlindungan Hukum Terhadap Notaris (Studi Atas Putusan Hakim Terhadap Tindak Pidana Pemalsuan Akta Otentik). Jurnal Hukum Pembangunan dan Ekonomi, Volume 5, Nomor 2, Juli 2017 .Hal 127.
Jika digunakan penafsiran original intent (penafsiran sesuai kehendak pembuat peraturan perundang-undangan) ${ }^{24}$, dari UU LLAJ, maka harus melihat perdebatan di dalam Buku Kompilasi Risalah atau Memorie van Toelichting (MvT) Pembahasan Rancangan Undang-Undang tentang LLAJ. Di dalam MvT terkait pasal 106 yang dulunya pasal 77 ini, Pemerintah yang diwakili Menteri Perhubungan menyampaikan bahwa:"...yang kedua, wajib konsentasi artinya tidak telepon genggam dan sebagainya". 25 Artinya jika dilihat dari kehendak pembuat undang-undang, maka segala kegiatan yang berhubungan dengan menggunakan telepon genggam, termasuk menggunakan GPS melalui smartphone dapat dikatakan menggangu konsentrasi.

Ambiguitas akan konsep "penuh konsentrasi" dalam Pasal 106 ayat (1) UU LLAJ ini, berkolerelasi dengan ambiguitas dari penerapan sanksi pidana dalam Pasal 283 UU LLAJ yang merupakan konsekuensi yuridis dari pelanggaran Pasal 106 ayat (1) tersebut.

Ambiguitas dalam pasal 106 ayat (1) jo. Pasal 283 UU LLAJ ini menyebakan penegak hukum mengambil tindakan untuk meberi sanksi pidana kepada setiap pengguna

24 Tanto Lailam, Penafsiran Konstitusi Dalam Pengujian Konstitusionalitas Undangundang Terhadap Undang-undang Dasar 1945. Jurnal Media Hukum, Volume 21, Nomor 1, Juni 2014 .Hal 92.

25 Buku Kompilasi Risalah Pembahasan Rancangan Undang-Undang tentang Lalu Lintas dan Angkutan Jalan 
telepon genggam, baik yang konvensional ataupun smartphone Hal ini karena UndangUndang tidak merumuskan secara eksplisit larangan penggunaan GPS. Artinya, menggunakan (memainkan) fitur-fitur GPS yang terdapat pada smartphone sambil mengemudi, akan ditindak oleh petugas. ${ }^{26}$ Tindakan polisi yang menindak pengguna telepon genggam tanpa pandang bulu tersebut, karena teori hubungan kausalitas yang dianut petugas polisi di lapangan adalah berdasarkan teori relevansi.

Teori relevansi ini dianut oleh Langenmeijer dan Mezger. Teori ini tidak dimulai dengan mengadakan perbedaan antara musabab dan syarat seperti teori menggeneralisir dan teori mengindividualisir, tetapi dimulai dengan menginterprestasi rumusan delik yang bersangkutan. ${ }^{27}$ Dari rumusan delik yang hanya memuat akibat yang dilarang dicoba untuk menentukan kelakuan-kelakuan apakah kiranya yang dimaksud pada waktu membuat larangan tersebut. Jadi pada teori relevansi ini pertanyaan pentingnya adalah : pada waktu undang-undang menentukan rumusan delik itu, kelakuan-kelakuan yang manakah yang

26 (Akhdi Martin Pratama, "Dirlantas: Pengendara yang Main HP Akan Ditilang, termasuk Ojek Online"), https://megapolitan.kompas.com/read /2018/03/04/15411181/dirlantas-pengendara-yang-main -hp-akan-ditilang-termasuk-ojek-online, diunduh pada Sabtu,9 Maet 2019, jam 08.00 WIB)

${ }^{27}$ Mohammad Ekaputra, Dasar-Dasar Hukum Pidana, cetakan ke-2, USU Press, Medan, 2015. Hlm.130. dibayangkan olehnya dapat menimbulkan akibat yang dilarang? ${ }^{28}$

Jika teori relevansi ini dikaitkan dengan larangan penggunan GPS melalui smartphone, dikarenakan kehendak pembuat undang-undang adalah melarang segala jenis kegiatan berkaitan dengan telepon genggam pada saat berkendara, maka penegak hukum tidak mempersoalkan parameter "yang menganggu konsentrasi", di mana yang dipentingkan adalah perbuatan, bukan akibat perbuatan.

\section{Legalitas Penggunan GPS melalui Smartphone Pasca Putusan Makhamah Konstitusi No. 23/PUU-XVI/2018}

Dalam Putusan Makhamah Konstitusi Nomor 005/PUU-III/2005, terkait dengan keraguan dalam implementasi suatu undangundang, dikatakan bahwa:

"Adanya keragu-raguan dalam implementasi suatu undang-undang akan memunculkan ketidakpastian hukum dalam praktik. Keadaan demikian dapat menimbulkan pelanggaran terhadap hak konstitusional sebagaimana diatur dalam Pasal 28D ayat (1) UUD 1945 yang menyatakan, "Setiap orang berhak atas pengakuan, jaminan, perlindungan dan kepastian hukum yang adil serta perlakuan yang sama di hadapan hukum." Ketidakpastian hukum demikian tidak sesuai dengan semangat untuk menegakkan prinsipprinsip negara hukum sebagaimana diamanatkan oleh Pasal 1 ayat (3) UUD 1945 yang secara tegas menyatakan bahwa Indonesia adalah negara hukum dimana kepastian hukum merupakan prasyarat yang tak dapat ditiadakan."

28 Moeljatno, Asas - Asas Hukum Pidana, Rineka Cipta, Jakarta, 2008.Hlml. 121-122) 
Dari putusan tersebut, dapat ditafsirkan bahwa ketentuan norma dalam Pasal 106 ayat (1) jo. Pasal 283 UU LLAJ yang menimbulkan keraguan dalam implementasinya, dimana sanksi pidana dalam norma tersebut dapat diberlakukan sesuai dengan kehendak aparat penegak hukum yang bertugas di jalan, tentunya menimbulkan pelanggaran terhadap hak konstitusional masyarakat yakni perlindungan dan kepastian hukum yang adil serta perlakuan yang sama di hadapan hukum bagi masyrakat.

Keambigiuitasan akan penafsiran Pasal 106 ayat (1) jo. Pasal 283 UU LLAJ tersebut, sejatinya juga bertentangan dengan asas nullum crimen nulla poena sine lege certa (sering disebut sebagai asas Lex Certa atau bestimmtheitsgebot) yang berarti rumusan tindak pidana yang dimaksud harus diuraikan unsur-unsurnya secara jelas, lengkap, dan tidak menimbulkan penafsiran ganda (ambigu). ${ }^{29}$

Dalam rangka memberikan kepastian hukum dan mencegah lebih banyaknya ketidakpastian penegakkan hukum akan Pasal 106 ayat (1) jo. Pasal 283 UU LLAJ, maka Makhamah Konstitusi, sebagai pengawal hak-hak konsitusional warga negara, khususnya terkait hak konstitusional terkait

29 Muchamad Iksan, Asas Legalitas Dalam Hukum Pidana : Studi Komparatif Asas Legalitas Hukum Pidana Indonesia Dan Hukum Pidana Islam (Jinayah). Jurnal Serambi Hukum, Volume 11, Nomor 1, Februari 2017 .Hal 8. kepastian hukum sesuai Pasal 28D ayat (1) UUD NRI 1945telah memberikan penafsiran terkait Pasal Pasal 106 ayat (1) jo. Pasal 283 UU LLAJ dalam Putusan Makhamah Konstitusi No. 23/PUU-XVI/2018.

Jika membaca sekilas Putusan Makhamah Konstitusi No. 23/PUUXVI/2018, maka kita akan melihat bahwa seolah-olah Makhamah Konstitusi melarang secara penuh penggunan GPS melalui smartphone selama berkendara. Makhamah Konstitusi seolah-olah dianggap tidak peka dengan perkembangan zaman, dimana banyak pengemudi taksi/ojek online yang mengharuskan mereka menggunakan GPS melalui smartphone selama berkendara. ${ }^{30}$

Ex falso quolibet, salah konsep, salah kesimpulan. $^{31}$ Kesalahan konsep tersebut lahir, karena banyak orang hanya melihat bahwa Makhamah Konstitusi menolak gugatan dari para pemohon untuk membuat Pasal 106 ayat (1) UU LLAJ, tidak mempunyai kekuatan hukum mengikat secara bersyarat sepanjang tidak dimaknai “dikecualikan untuk penggunaan aplikasi sistem navigasi yang berbasiskan satelit yang biasa disebut GPS yang terdapat dalam smartphone". Banyak orang melihat amar

${ }^{30}$ (Muhammad Ridwan, "Putusan MK soal GPS Dianggap Merugikan Ojol"), https://www.jawapos.com /nasional/31/01/2019/putusan-mk-soal-gps-dianggapmerugikan-ojol, diunduh pada Minggu 10 Maret 2019, jam 17.00 WIB)

${ }^{31}$ Dhia Al Uyun, Sic Et Non: Kebebasan Dan Pembatasan Hak Kemudahan Dan Perlakuan Khusus. Yuridika, Volume 31, Nomor 1, April 2016 .Hal 4. 
putusan tersebut, tanpa melihat pertimbangan hukum dari Makahamah Konstitusi.

Dalam pertimbangan Putusan Makhamah Konstitusi No. 23/PUUXVI/2018, Makhamah Konstitusi menilai bahwa lahirnya UU LLAJ adalah untuk menekan angka kecelakaan lalu lintas yang semakin tinggi, sehingga perlu ada upaya pengaturan yang diarahkan salah satunya pada penanggulangan angka kecelakaan lalu lintas secara komprehensif mulai dari pencegahan hingga penegakan hukumnya. Salah satu upaya yang dilakukan adalah dengan melakukan pengaturan norma baru terkait "mengendara dengan penuh konsentrasi". 32

Makhamah Kontitusi menilai, bahwa menggunakan telepon seluler yang di dalamnya terdapat berbagai fitur termasuk aplikasi sistem navigasi yang berbasiskan satelit yang biasa disebut GPS pada saat berkendara, dalam batas penalaran yang wajar termasuk hal yang dapat mengganggu konsentrasi berlalu lintas yang dapat berdampak pada kecelakaan lalu lintas. Dengan kata lain, penggunaan GPS dapat dibenarkan sepanjang tidak mengganggu konsentrasi pengemudi dalam berlalu lintas. Artinya, tidak setiap pengendara yang menggunakan GPS serta-merta dapat dinilai mengganggu konsentrasi mengemudi yang membahayakan pengguna jalan lainnya yang

32 Pertimbangan Hakim halaman 149 Putusan MK No 23/PUU-XVI/2018 Hal.148. dapat dinilai melanggar hukum, sehingga penerapannya harus dilihat secara kasuistis. ${ }^{33}$ (garis bawah dari penulis)

Dari pertimbangan Makhamah Konstitusi tersebut, dapat dilihat bahwa sebenarnya Makhamah Konstitusi berpendapat bahwa penggunaan GPS dapat dibenarkan, sepanjang tidak mengganggu konsentrasi pengemudi dalam berlalu lintas, karena tidak setiap pengendara yang menggunakan fitur GPS akan serta-merta dapat dinilai terganggu konsentrasinya dalam mengemudi. ${ }^{34}$ Tentunya, penerapan pasal 106 ayat (1) tersebut juga harus dilihat secara kasuistis.

Dari pertimbangan hakim Makhamah Konstitusi tersebut, dapat dilihat, bahwa Makhamah Konstitusi melihat penjelasan suatu pasal sebagai klarifikasi undangundang, yang menekankan pada interpretasi sebagai proses, yaitu "pemberian suatu makna kepada suatu pernyataan melalui suatu pernyataan lain, yang mempunyai makna yang dimaksud". ${ }^{35}$ Dalam hal ini Penjelasan Pasal 106 ayat (1) UU LLAJ menginterpretasikan suatu pernyataan "penuh konsentrasi” dengan memberikan suatu alternatif rumusan yang ditegaskan oleh

${ }^{33}$ Pertimbangan Hakim halaman 154 Putusan MK No 23/PUU-XVI/2018 Hal.148.

34 Mery Christina Putri, Distorsi Informasi "Larangan Penggunaan Gps Saat Berkendara". Majalah Konstitusi, Nomor 144, Februari 2019 .Hal 9.

35 M.A. Loth, Bahasa dan Hukum Sebuah Metodologi Kecil, Dirjen Peraturan Perundangundangan Dep. Hukum dan HAM, Jakarta, 2007, dalam Putusan MK No 23/PUU-XVI/2018 
suatu instrumen atau kondisi tertentu yang akan mengarah pada maksud "penuh konsentrasi." Dalam hal ini "penuh konsentrasi" dimaksudkan sebagai makna yang tidak terganggu oleh suatu instrumen atau keadaan. Dengan demikian, penekanan norma adalah seseorang ketika mengemudikan kendaraan wajar dan penuh konsentrasi, dan tidak ada gangguan apapun yang memengaruhi kemampuan dalam mengemudikan kendaraan.

Dengan demikian, ketentuan Pasal 106 ayat (1) beserta penjelasannya dan Pasal 283 UU LLAJ bukan ditujukan pada instrumennya, tetapi hilang konsentrasinya akibat segala tindakan yang menyebabkan gangguan konsentrasi dalam mengemudi di jalan. Artinya rumusan ketentuan pasal tersebut menggunakan teori relevansi untuk menentukan dahulu akibat keterjadian atau akibat yang terjadi, misalnya pelanggaran marka jalan dan kecelakaan lalu lintas, kemudian ditentukan sebabnya, misalnya sedang melakukan kegiatan dan keadaan apa saat mengemudikan di jalan, sehingga konsentrasi terganggu.

Hal ini menunjukkan penggunaan telepon dan fiturnya, misalnya penggunaan GPS, bukanlah syarat pelanggaran yang dituju dalam undang-undang, tetapi "terganggunya perhatian, yang mengakibatkan gangguan konsentrasi dalam mengemudi di jalan."
Penggunan GPS melalui Smartphone yang Tidak Menggangu Konsentrasi

Meskipun Putusan Makhamah No. 23/PUU-XVI/2018, mengatakan bahwa penggunan GPS melalui smartphone selama berkendara diperbolehkan, asalkan tidak menganggu konsentrasi, namun Putusan Makhamah Konstitusi tersebut tidak memberikan pengaturan teknis terkait, seperti apa penggunan GPS melalui smartphone selama berkendara yang tidak menganggu konsentrasi. Jika kita lihat, bahwa penggunan GPS yang tidak menganggu konsentrasi tersebut sebenarnya ada beberapa cara. Misalkan cara yang diusulkan oleh Kakorlantas Polri Irjen Pol Royke Lumowa, adalah dengan menyetel GPS pada tujuan yang hendak dicapai, kemudian meletakkan smartphone pada tempat yang mudah dilihat dan mengaktifkan fitur panduan dengan suara, sehingga hanya dipandu oleh suara, tidak boleh melihat smartphone berulang kali, cukup sesekali saja secara sekilas. ${ }^{36}$ Cara lain yang disarankan oleh Kadiv Humas Polri Irjen Setyo Wasisto adalah dengan mengaktifkan GPS terlebih dahulu untuk menentukan posisi, kemudian menuju tempat tujuan yang dituju. Jika ingin melihat GPS lagi, maka menepi untuk berhenti terlebih dahulu untuk melihat lokasi. Setelah mengetahui lokasi, kembali berjalan lagi

\footnotetext{
36 (Kumparan, "Kakorlantas Polri: Pakai GPS di HP Boleh, Asal Jangan Dipegang”), https://kumparan.com/@kumparannews/kakorlantaspolri-pakai-gps-di-hp-boleh-asal-jangan-dipegang, diunduh pada Minggu 10 Maret 2019, jam 19.39 WIB)
} 
menuju lokasi tersebut. ${ }^{37}$ Cara ini selain dianggap tidak menggangu konsentrasi saat berkendara, juga cara ini menjamin keselamatan stakeholder para pengguna jalan.

\section{PENUTUP}

Lahirnya Putusan Makhamah Konstitusi NO 23/PUU-XVI/2018 telah mengakhiri ambiguitas terkait penafsiran Pasal 106 ayat (1) jo. Pasal 238 UU LLAJ. Ambiguitas tersebut awalnya muncul terkait penafsiran "penuh konsentrasi" dalam penjelasan Pasal 106 ayat (1) tersebut. Jika yang digunakan adalah penafsiran gramatikal, berarti mengizinkan penggunan GPS melalui smartphone selama berkendara asalkan, tidak menganggu konsentrasi, namun jika yang digunakan adalah penafsiran original intent, dengan menggunakan pendekatan kausalitas melalui teori relevansi, maka yang dilarang adalah segala kegiatan yang diatur dalam penjelasan Pasal 106 ayat (1).

Putusan Putusan Makhamah Konstitusi NO 23/PUU-XVI/2018 yang salah diartikan melarang penggunan GPS melalui smartphone, karena menolak pemohonan penggungat, justru dalam pertimbangan hukumnya, mengatakan bahwa penggunaan GPS dapat dibenarkan sepanjang tidak

${ }^{37}$ (Audrey Santoso, "Soal Berkendara Pakai GPS, Ini Klarifikasi Polri"), https://oto.detik.com/berita/d3901362/soal-berkendara-pakai-gps-ini-klarifikasipolri, diunduh pada Minggu 10 Maret 2019, jam 19.39 WIB) mengganggu konsentrasi pengemudi dalam berlalu lintas. Artinya, tidak setiap pengendara yang menggunakan GPS sertamerta dapat dinilai mengganggu konsentrasi mengemudi yang membahayakan pengguna jalan lainnya yang dapat dinilai melanggar hukum, sehingga penerapannya harus dilihat secara kasuistis.

\section{DAFTAR PUSTAKA}

\section{Buku-Buku}

M.A. Loth. Bahasa dan Hukum Sebuah Metodologi Kecil. Dirjen Peraturan Perundang-undangan Dep. Hukum dan HAM, Jakarta, 2007, dalam Putusan MK No 23/PUU-XVI/2018.

Moeljatno. Asas-Asas Hukum Pidana. Rineka Cipta, Jakarta, 2008.

Mohammad Ekaputra. Dasar-Dasar Hukum Pidana (cetakan ke-2). USU Press, Medan, 2015.

Mukti Fajar \& Yulianto Achmad. Dualisme Penelitian Hukum Normatif dan Empiris. Pustaka Pelajar, Yogyakarta, 2013.

Peter Mahmud Marzuki. Penelitian Hukum. Kencana Prenada Media Group, Jakarta, 2005.

\section{Artikel dalam Jurnal}

Agus Priono et.al. Penerapan Teori Penafsiran Hukum Oleh Hakim Sebagai Upaya Perlindungan Hukum Terhadap Notaris (Studi Atas Putusan Hakim Terhadap Tindak Pidana Pemalsuan Akta Otentik). Jurnal Hukum Pembangunan dan Ekonomi, Volume 5, Nomor 2, Juli 2017.

Ahmar Amad. Perkembangan Teknologi Komunikasi Dan Informasi: Akar Revolusi Dan Berbagai Standarnya. 
Jurnal Dakwah Tabligh, Volume 13, Nomor 1 Juni 2012.

Dhia Al Uyun. Sic Et Non: Kebebasan Dan Pembatasan Hak Kemudahan Dan Perlakuan Khusus. Yuridika, Volume 31, Nomor 1, April 2016.

Janedri M. Gaffar. Peran Makhamah Konstitusi dalam Perlindungan Hak Asasi Manusia. Jurnal Konstitusi, Volume 10, Nomor 1 Maret 2013.

Muchamad Iksan. Asas Legalitas Dalam Hukum Pidana: Studi Komparatif Asas Legalitas Hukum Pidana Indonesia Dan Hukum Pidana Islam (Jinayah). Jurnal Serambi Hukum, Volume 11, Nomor 1, Februari 2017.

Muhamad Ngafifi. Kemajuan Teknologi Dan Pola Hidup Manusia Dalam Perspektif Sosial Budaya. Jurnal Pembangunan Pendidikan: Fondasi dan Aplikasi, Volume 2, Nomor 1 Juni 2012. Hlm. 34.

Oly Vina Agustine. Keberlakuan Yurisprudensi pada Kewenangan Pengujian Undang-Undang dalam Putusan Mahkamah Konstitus. Jurnal Konstitusi, Volume 15, Nomor 3, Juni 2018 .

Putu Agus Yudisuda Indrakarna et.al. Rancang Bangun Sistem Informasi Pelacakan Dan Pemantauan Paket Kiriman Berbasis Web Dengan Bantuan Mobile Android, Jurnal Sistem informasi \& Komputer Akuntansi Volume 1 Nomor 2012.

Tanto Lailam. Penafsiran Konstitusi Dalam Pengujian Konstitusionalitas Undang-undang Terhadap Undangundang Dasar 1945. Jurnal Media Hukum, Volume 21, Nomor 1, Juni 2014.

Yosephat Suryo Susilo et.al. Sistem Pelacakan Dan Pengamanan Kendaraan Berbasis Gps Dengan Menggunakan Komunikasi Gprs. Jurnal Ilmiah Widya Teknik, Volume 13, Nomor 1 Mei 2014.

\section{Artikel dalam Prosiding}

Oktri Mohammad Firdaus. Analisis Implementasi Global Positioning System (Gps) Pada Moda Transportasi Di Pt. "X". Proceeding Seminar on Application and Research in Industrial Technology (SMART), Yogyakarta, 2010.

\section{Artikel dalam Sumber Online}

Agus Sahbani. Alasan MK Tetap Larang Penggunaan GPS. Retrieved from https://www.hukumonline.com/berita /baca/1t5c542c0cb2fdf/alasan-mktetap-larang-penggunaan-gps. 2019.

Akhdi Martin Pratama. Dirlantas: Pengendara yang Main HP Akan Ditilang, termasuk Ojek Online Retrieved from https://megapolitan.kompas.com/read /2018/03/04/15411181/dirlantaspengendara-yang-main-hp-akanditilang-termasuk-ojek-online.

2019.

Arris Riehady. Nasib GPS di Mobil Setelah Ada Larangan Menggunakannya. Retrieved from https://www.seva.id/otomotif/blog/na sib-gps-di-mobil-setelah-adalarangan-menggunakannya//. 2019.

Audrey Santoso. Soal Berkendara Pakai GPS, Ini Klarifikasi Polri. Retrieved from https://oto.detik.com/berita/d3901362/soal-berkendara-pakai-gpsini-klarifikasi-polri. 2018.

Edi Nugroho. Simak, Keuntungan Membeli Mobil yang Dilengkapi GPS. Retrieved from http://banjarmasin.tribunnews.com/2 017/02/14/simak-keuntunganmembeli-mobil-yang-dilengkapi-gps. 2017.

Eko Aria Wibowo. GPS Ponsel Akan Dirazia, Ini Trik Pengemudi Ojek Online. Retrieved from https://otomotif.tempo.co/read/11723 40/gps-ponsel-akan-dirazia-ini-trik- 
pengemudi-ojek-

online/full\&view=ok. 2019.

Emanuel Kure dan Abdul Muslim. Pengguna Smartphone RI Tumbuh 30\%. Retrieved from https://id.beritasatu.com/home/pengg una-smartphone-ri-tumbuh30/143720 2016

Irman Rismawan. GOJEK Beri Cara Aman Driver Ojek Online Gunakan GPS. Retrieved from http://www.tribunnews.com/techno/2 019/02/12/gojek-beri-cara-amandriver-ojek-online-gunakan-gps. 2019.

Kumparan. Kakorlantas Polri: Pakai GPS di HP Boleh, Asal Jangan Dipegang. Retrieved from https://kumparan.com/@kumparanne ws/kakorlantas-polri-pakai-gps-dihp-boleh-asal-jangan-dipegang. 2018.

Mohammad Zacky. Pakai GPS Sambil Nyetir Ditilang, Driver Online: Jangan Hanya Kami. Retrieved from https://news.detik.com/berita/d3898409/pakai-gps-sambil-nyetirditilang-driver-online-jangan-hanyakami. 2018.

Muhammad Ridwan. Putusan MK soal GPS Dianggap Merugikan Ojol. Retrieved from

https://www.jawapos.com/nasional/3 1/01/2019/putusan-mk-soal-gpsdianggap-merugikan-ojol. 2019.

Nadia. Fungsi GPS. Retrieved from http://www.fungsiklopedia.com/fung si-gps/. 2016.

\section{Artikel dalam Majalah}

Mery Christina Putri. Distorsi Informasi "Larangan Penggunaan Gps Saat Berkendara". Majalah Konstitusi, Nomor 144, Februari 2019.

\section{Peraturan Undang-Undang}

Putusan Makhamah Konstitusi Nomor 005/PUU-III/2005

Putusan Makhamah Konstitusi Nomor 23/PUU-XVI/2018

Undang-Undang Dasar Negara Republik Indonesia 1945

Undang-undang Nomor 22 Tahun 2009 tentang Lalu Lintas dan Angkutan Jalan.

Undang Nomor 12 Tahun 2011 Tentang Pembentukan Peraturan PerundangUndangan 